21 Golding J, Pembrey M, Jones R. ALSPAC - the Avon Longitudinal Study of Parents and Children. I. Study methodology. Paediatr Perinat Epidemiol 2001 15: 74-87.

22 Shaffer D, Fisher $\mathrm{P}$, Lucas CP, Dulcan MK, Schwab-Stone ME. NIMH Diagnostic Interview Schedule for Children Version IV (NIMH DISC-IV). Description, differences from previous versions, and reliability of some common diagnoses. J Am Acad Child Adolesc Psychiatry 2000; 39: 28-38.

23 World Health Organization. Schedules for Clinical Assessment in Neuropsychiatry. American Psychiatric Research, 1994.

24 Wechsler D, Golombok S, Rust J. Weschler Intelligence Scale for Children (3rd Edition) (WISC-III UK). The Psychological Corporation, 1992.

25 Wolke D, Woods S, Bloomfield L, Karstadt L. The association between direct and relational bullying and behaviour. J Child Psychol Psychiatry 2000; 41: 889-1002.

26 Office of Population Censuses and Surveys. Standard Occupational Classification. TSO (The Stationery Office), 1991.

27 Osborn AF, Butler NR, Morris AC. The Social Life of Britain's Five-Year-Olds. A Report of the Child Health and Education Study. Routledge \& Kegan, 1984.

28 Dale A, Marsh C. The 1991 Census User's Guide. Office for National Statistics, 1993.

29 Goodman R. The Strengths and Difficulties Questionnaire: a research note. J Child Psychol Psychiatry 1997; 38: 581-6.
30 van Buuren S, Boshuizen $\mathrm{H}$, Knook L. Multiple imputation of missing blood pressure covariates in survival analysis. Stat Med 1999; 18: 681-94.

31 Landis J, Koch G. The measurement of observer agreement for categorical data. Biometrics 1977; 33: 159-74.

32 Wing JK, Cooper JE, Sartorious N. Measurement and Classification of Psychiatric Symptoms. Cambridge University Press, 1974.

33 American Psychiatric Association. Diagnostic and Statistical Manual of Mental Disorders (4th edn) (DSM-IV). APA, 1995.

34 Royston P. Multiple imputation of missing values. Stata Journal 2004; 4: 227-41.

35 Reichenberg A, Weiser M, Caspi A, Knobler HY, Lubin G, Harvey PD, Rabinowitz J, Davidson $\mathrm{M}$. Premorbid intellectual functioning and risk of schizophrenia and spectrum disorders. J Clin Exp Neuropsychol 2006; 28 : 193-207.

36 Cannon TD, Bearden CE, Hollister JM, Rosso IM, Sanchez LE, Hadley T. Childhood cognitive functioning in schizophrenia patients and their unaffected siblings: a prospective cohort study. Schizophr Bull 2000; 26 379-93.

37 Achenbach TM, Rescorla LA. Developmental issues in assessment, taxonomy, and diagnosis of psychopathology: life span and multicultural perspectives. In Developmental Psychopathology. Volume 1: Theory and Method (eds D Cichetti \& DJ Cohen): 139-80. John Wiley \& Sons, 2006.

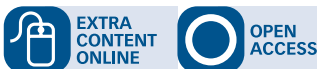

\title{
100 Working with the government
}

Louis Appleby

Governments are devious, self-serving, up to no good. Just as psychiatrists are sinister, voyeuristic, not really doctors. Prejudice against authority figures is harmless and possibly healthy. Until we start to believe it. In fact, governments are just people. They have the same failings as the rest of us, but like us they are trying to do the right thing. What they do not have is clinical experience, and there lies our big chance. The government believes that power lies with clinicians and is desperate for our support. We can lead mental healthcare reform - unless, of course, we prefer the prejudice. 